"Mircea cel Batran" Naval Academy Scientific Bulletin, Volume XIX - 2016 - Issue 2 The journal is indexed in: PROQUEST / DOAJ / Crossref / EBSCOhost / INDEX COPERNICUS / DRJI / OAJI / JOURNAL INDEX I I2OR / SCIENCE LIBRARY INDEX / Google Scholar I Academic Keys/ ROAD Open Access I Academic Resources / Scientific Indexing Services / SCIPIO / JIFACTOR

\title{
THE PERSONALITY OF THE NAVAL LEADER - A STRUCTURED COMPLEX
}

\author{
Carmen Luminita COJOCARU ${ }^{1}$ \\ ${ }^{1}$ Associate Professor Ph.D. "Mircea cel Batran" Naval Academy, Constanta, Romania
}

\begin{abstract}
The study aims to analyze the personality of the navy leader from the perspective of a hypercomplex, probabilistic, open system, highly influenced by their profession and the specific of their activities at sea. We have tried to capture as much as possible, the relations of interaction, the inter-influence, compensation, and feedback placed among the components of personality.

It also observes the way in which the personality system tends toward successive balancing and rebalancing under the influence of external disturbance stimuli.

The study pleads for the growth of the leader through training, personal development, teamwork experience, interpersonal perceptions with minimal errors, both through well-being and through personal and professional efficiency; the paper also pleads for maximization of the effectiveness of naval leadership.
\end{abstract}

Key words: personality, maturity, leadership naval systems approach.

\section{ARGUMENT}

Modern world calls more than ever for performance, competitiveness and rapid resolution problems centered on solutions, efficiency and effectiveness in all areas of life, especially in the workplace.

Studies in the naval field signal a surprising fact, i.e. most of the accidents and incidents at sea, with casualties and material losses, is mostly due to the human element. And here we do not make reference to the inability of the intellect otherwise well-trained, and with great learning potential for acquiring vocational issues, on the basis of anchor ideas, but to the quality of psychological personality development, to the personal equation that requires maturity, self-actualization, develop coping mechanisms that permit the sailor to become operational socially and professionally, to keep the inner balance in uncertain and risky specific context of life and work at sea.

Hence comes the urge to study human personality in general, and the personality of the vocational naval leader in particular, to understand the laws of its functioning and adaptation, to describe ways of useful training appropriate for the development of the naval activities according to their demands. That is why we approach the optimization of naval leadership from a completely different probabilistic paradigm, as opposed to the traditionalist one, which we can state as follows: if we focus on the optimization of the leader's personality in terms of its plenary development, we can expect to obtain professional efficiency sine qua non, as Schein proposes in "the complex human model." This paradigm allows us to continue to address the naval leader's personality in a more flexible, complex, multilateral way, according to a mixed interpretative leadership model.

\section{NAVAL LEADER'S PERSONALITY - systemic approach}

Some time ago, Ludwig von Bertalanffy, system defined the system as being "any number of elements among which there exist regular, nonrandom interactions ".

We understand that the relationship between element and system is extremely dynamic, continuously changing, the constituent elements of the system being structured into subsystems which function according to rules, to a certain order, and also, order, or non-randomness.

So what at a certain moment was an element becomes a subsystem in interaction with other systems and subsystems; in such a case extremely complex interaction factors intervene, along with interconnectedness, interdependence, compensation, feedback, feedback before...

Thus, the human psychic system records successive balancing and rebalancing, or imbalances of a multivariate formula, always tending toward equilibrium, or efficient- adaptive functioning.

Let us not forget that the naval profession imposes repeated alternative adjustments and readjustments (not only from a practical perspective) in what the procedural, on board tasks are concerned in relation to more general periodic changes in the external environmental situational conditions. Physiological biorhythm work climate, multicultural, multi-religious human diversity, age, training and professionalism, uncertainty or risk are other factors that should be considered.

In these circumstances, the human psyche works mainly probabilistically, according to M. Golu's successful expression the human psyche is "an open hyper-complex, probabilistic, dynamic, 


\section{"Mircea cel Batran" Naval Academy Scientific Bulletin, Volume XIX - 2016 - Issue 2 The journal is indexed in: PROQUEST / DOAJ / Crossref / EBSCOhost / INDEX COPERNICUS / DRJI / OAJI / JOURNAL INDEX I I2OR / SCIENCE LIBRARY INDEX / Google Scholar / Academic Keys/ ROAD Open Access I Academic Resources / Scientific Indexing Services / SCIPIO / JIFACTOR}

system." There were other voices, too, in literature that made reference to the synergistic approach to explain the irreducible peculiarities and regularities of the human psyche, perhaps the most authorized is that of $\mathrm{H}$. Haken who defined synergy as "simultaneous action pointing in the same direction, for performing the same function, of several agents, being the science of selforganization or auto - structuring of systems, regardless of their physical, chemical, biological, or social nature, based on collaboration and organic cooperation of components and subsystems".

H. Haken, in his explanations, shows the principles of "dynamic instability, creative imbalance", and also" synchronous cooperation and cooperation of interactions", both applicable to human psychic system.

Defining of personality as an "universalia" principle of ancient human concerns which was addressed not just from the multidisciplinary point of view, but also from side of its plurality of theories, models, or patterns.

Specialists agree on the concept of personality as an objective perceived reality and psychological wholeness of the leader in front of his followers.

It's about the living man, the concrete man who works in a team, makes decisions, knows his team/ crew, has a sense of humor...

Scientifically, Meili admits that "personality is the most complex and therefore the most important, complex subject of psychology"; personality is the quintessential human entity of bio-psycho-sociocultural nature acting on human self, and on the environment, being influenced by it, and dominating the environment, possessing it, the human being changes himself with it, valorize himself and others, transformer, sensing, this way, the world.

From this perspective, we can agree with the definition of personality given by T. Cretu, i.e. "personality is a complex structure involving a set of substructures and operating systems."

In this case, the focus is on the type of relationships that are established in the composition of tripartite personality of the naval leader, sensing the teleological wholeness of human personality and, especially, opening personality toward the outside socio- cultural environment, at which it must accommodate through activity.

Ontogenetically, the first side of personality, long studied by specialists, is the side expressing how much psychical energy is there in the mental and psychic system, and especially, how it is consumed, valorized. Of course, we make reference to temperament, considered by many authors as "dynamic-energy side" of personality; temperament is defined by $\mathrm{G}$. Allport himself as "emotional foundation of personality."

With an intuition of a genius, Hippocrates, father of medicine, found significant correlations between the natural elements (earth, water, air, fire) and psychic elements constituents, developing temperamental types whose names have been preserved until today: choleric, sanguine, phlegmatic and melancholic.

Later, the human need for scientific knowledge and pragmatic reasons, based on various criteria, other scientists broadened the scope of the investigation on the types of temperament. For example, C.G. Jung, inspired by bipolarity and opposites of the universe (life - death day - night, health - disease, flux - reflux), took into account the psychic facts and concluded that the human personality is differently oriented, either toward the outside - extraversion, or toward the inner world - introversion.

So, irrespective of the temperamental taxonomies, authors agreed on the following: temperament has an emotional and reactive part, nature. They have made extensive descriptions of it in terms of sensibility, at the intellectual, activity, or psycho-behavioral level. Thus, at more rigorous analysis, we note that Jung's extraversion requires Hippocrates' sanguine and choleric temperaments, while introversion summarizes the other two types, phlegmatic and melancholic.

In psychological literature, there are some controversial issues concerning temperament, which we want to debate. One of them concerns the question whether the types of temperament are pure and the answer comes quickly at hand: there are no pure types of temperamental, but in our psyche by analogy with states of mental health, emphasizing personality states or psychopathology, elements of all kinds, some of them being predominant psychological traits and describing the traits for a specific for a certain classification.

Another general problem of temperament that was of interest to scientists is the way of expression of the types of temperament, namely that temperament does not express the content of the psychic life, it is merely a form, a way of showing the content of the psyche in the outside world, without having epistemic or axiological values. If we want to put it metaphorically, it is just a costume that the social actors wear on the stage of life.

Deepening the temperament issues, with strong impact on functional activities of human and social efficiency and effectiveness, we come to the question whether temperament is inborn or 


\section{"Mircea cel Batran" Naval Academy Scientific Bulletin, Volume XIX - 2016 - Issue 2 The journal is indexed in: PROQUEST I DOAJ / Crossref / EBSCOhost / INDEX COPERNICUS / DRJI / OAJI I JOURNAL INDEX I I2OR / SCIENCE LIBRARY INDEX / Google Scholar / Academic Keys/ ROAD Open Access I Academic Resources / Scientific Indexing Services / SCIPIO / JIFACTOR}

acquired. If temperament had been proven to be entirely innate, it should now be excluded from the composition of personality, thrown through the back door because all the psychic structures are totally acquired, not having a hereditary component.

On the other hand, research has shown a strong commitment to determining the type of superior nervous activity, of what Pavlov proved to be the excitation and inhibition of brain, and their "game" in achieving the balance of neuronal metabolism. It is easy to deduce that we inherit the cerebral genetic material with its particularities, and when the nervous excitative processes prevail, they will lead to extraversion and, conversely, when brain inhibition prevails, we will have introverted temperament types.

Despite having a significant inherited component temperament is hierarchically subordinated to character in the personality system, which facilitates or inhibits its free expression according to the principle of adaptation to the demands of the surrounding reality.

In arguing this, we can quote I. Radu who states that "between genes and behavior the environment and individual history intercede ", or we can paraphrase $\mathrm{M}$. Zlate who concludes that "temperament is a psychological structure, which, although largely determined genetically, is, in its final expression and, almostly, functional expression, also determined and shaped by socio - cultural conditions of the individual.

The hereditary influence on psycho - behavior is not direct; it is mediated, and filtered by the sociocultural. "

Adapting these assertions to the activity of the naval leader, considering the professionalization of temperament, we can describe a number of recommendations on specialties and work attributions in the naval field, according to the criteria necessary for an efficient work: time for perceiving or collecting signals and time for reaction, the ability to concentrate attention, estimation of difficulties of successful achieving tasks and own capacities, faster decision making capacity, organizational capacity, personal relationships guiding.

Despite the temperament is not a psychological criteria in selection for distributing work tasks, an effective leader will consider in psychological terms the temperamental type of his subordinates, ensuring that each of them performs those activities which are consistent with their own potential.

Another personality component needed in achieving an effective leadership refers to skills, to the instrumental side of personality, "a complex of processes and individual psychological characteristics, structured in an original way that allows the successful completion of certain tasks." (M. Zlate). Also, the concept of efficiency in work or conduct is discussed here, along with effective realization of activity at a higher quality level that exceeds the performance of mediocre automatic tasks. In this respect, different degrees of achievement of activities, from simple to complex: predispositions, abilities, skills, automatism, skills with the highest levels of complexity, like talent and genius can be distinguished.

Psychic structures acquired mainly through hard work, best skills are formed at the highest level when there is a happy coincidence between the psychological skills potential and the quality of the stimuli that the environment put into the equation. So, work, as a place where and through, human psyche is formed and expressed, through its content and ways of expression, can intervene to shape these highly malleable and extremely plastic psychic structures.

Returning to the personality of the ship leader, we realize that beyond the formation of complex skills related to the professional, technical area, special emphasis is placed on the psychosocial skills meant to give the leader the possibility to ensure the psychological management of their team. Among them, we include: work in a working group, training, coaching and increasing the professional motivation, capacity to build team cohesion and create a positive work environment, the ability to know the subordinates, to be empathic cognitive or emotional.

Closely related to the above mentioned ideas, the naval leader's personality expresses a way of being, a printed "stamp" on the behavior, known scientifically as character or psycho-moral profile, since his personality and behavior comply with rules and criteria for consistency, stability, unity, and ethical value.

Indeed, under the system of personality, character is what gives human value, which contains a set of attitudes and traits that transform man from consumer values into manufacturer values. Among these, include: the world view and life style of work, belief, beliefs, attitudes, ideals, aspirations...

Consistent with the systemic theory, we can say, making refer to the character as a "relationalvalue side of personality with a role in selfadjustment" (M Zlate).

We can also state that all the ways for the development of consciousness, self-image, the attitude towards work and towards others, the feelings for a group, along with the character traits are not dispersed; on the contrary, they are 


\section{"Mircea cel Batran" Naval Academy Scientific Bulletin, Volume XIX - 2016 - Issue 2 The journal is indexed in: PROQUEST I DOAJ / Crossref / EBSCOhost / INDEX COPERNICUS / DRJI / OAJI I JOURNAL INDEX I I2OR / SCIENCE LIBRARY INDEX / Google Scholar / Academic Keys/ ROAD Open Access I Academic Resources / Scientific Indexing Services / SCIPIO / JIFACTOR}

interrelated and integrated into a unitary, stable, constant structure having great adaptive value.

We may infer the need for training, exercising and expressing of a naval leader's specific character traits, which are essential in building excellence in leadership. Among them, we could mention: voluntary character traits (activism, courage, perseverance, determination, autonomy, firmness), interpersonal features (sociability, social authority and prestige in team work), traits that can express psychological factors of personality (integrity, dynamism, strength of character), and the list may go on.

Exigencies of character useful in naval leadership, depending on the specific of life and work at sea, can extend their sphere of interpretation by: responsibilities, psychic resistance to intense and prolonged or aggressive psychological risk factors and unforeseen situations, increased tolerance to repetitive actions, to frustration and stress, selfcontrol and, especially, a great capacity to adjust to all kind of people and situations.

The character, as a vital, synthesizer part of personality, has the extremely important functions being, before everything, the mediating psychic structure between human being and the surrounding reality through interpersonal relationships.

In this way, men are able to first govern themselves, to filter out of the external environment those various and randomly conditions which they later selective transform and use to their own benefit, and finally export them in the form of personalized, genuine attitudes, expressing uniqueness, originality.

\section{RELATIONS BETWEEN THE COMPONENTS OF THE NAVAL LEADER'S PERSONALITY}

Remaining in the area of systemic approach of the naval leader's personality, we regard personality as a system in which the components are organized, structured, ranked so as to become permanent; hyper complex interaction, interrelation, inter influence, interdependence, compensation and feedback appear among its components. There is an effort of permanent evolution of the personality system in which there can be positive emergencies, beneficial and constructive for personality, or, conversely, there can also appear erosions, imbalances, divisions, with immediate influence on productivity and mental adjustment.

This may be one of the arguments that explain the uniqueness or originality of personality architectonics, which is emphasized by the individual specific and by the unique personal equation.
The mutual interrelationship between character and temperament have different effects: temperament which colors the form manifestation of psychic life, might otherwise act temperamental expression of a particular type, extravert or introvert, impact on interpersonal perception.

Thus, the leader can be perceived as friendly, sociable, active, generous, enterprising or, conversely, as calm, meticulous, withdrawn, uncommunicative.

On the other hand, the behavioral activism, consequence of cerebral activism, may create difficulties in training and practicing certain character traits that require persistence and tenacity, bordering on psycho-behavioral immaturity. Having an integrator role, most often, the character takes possession over temperament, selects, inhibits, and retains certain temperamental manifestations with maladaptive effect, thus enhancing other temperamental behaviors depending on the requirements of reality.

So the character capitalizes and valorizes the temperamental manifestations depending on the context, adapting the individual to his working environment, and also to the socio-cultural macro system. Only the balanced game of the "power" held by each of these components of personality over the others can lead to balance and functionality within normal range.

When one of these sides of personality dominates excessively over the others, disruptions appear: either the character dominates the temperament and the person is hyper-controlled and censored, reprimanding their temperament manifestation and behave like an automaton, or, conversely, when temperament dominates over character, which it perceives as a laisser-faire leader, the behavior tends to show weaknesses, non-control, frustration.

The mutual inter influence between temperament and skills focuses on the general premise condition of temperament in relation to skills; on one and the same temperament many and varied skills can be developed. Extroverted temperament, more excitable and unbalanced, tends to inhibit the formation of skills involving sustained effort, over a long period of time, as compared to the introverted temperament, which has a facilitator role. In both situations, the compensation mechanisms intervene; a correctly formed skill, by the success achieved, will lead to the increase of intrinsic motivation and will subordinate the temperamental tendencies to the level of aspiration which has to be obtained and even exceeded. 
"Mircea cel Batran" Naval Academy Scientific Bulletin, Volume XIX - 2016 - Issue 2

Equally interesting and important is the study of the relationship between character and skills, in which character, by certain traits and attitudes, such as persistence, diligence, sense of duty, passion for a particular type of activity, may promote the formation of skills that lead to performance. On the other hand, the character receives a positive feedback from successful results due to highly positive skills, and then will mobilize to the maximum the other psychic structures such as attention, motivation, self-will, affection, to achieve excellence in skills.

We note that no component of personality should be considered an independent entity. It should be regarded at in relation to all the other sides of personality, with the other components of psychic life. The central place in the personality system is held by character, as an integrative psychical characteristic which subordinates, enhances control, exploits and capitalizes to the maximum all the other components.

To use a metaphor, we could say that in the system of leadership, the leader can be associated with the character, in the personality system, the former having the same privileged functions.

\section{CONCLUSIONS}

We stress the importance of a central concept of the naval leader's personality, with overwhelming effect on the style of leadership, on authority, power and prestige, decision-making ability, and motivation of subordinates.

Equally, through the maturity and personal personality, the naval leader will successfully fulfill tasks related to building effective multicultural team work, will acquire knowledge for the correct perception of subordinates, and will properly use the potential of human resources, along with professional success celebration.

Thus, between man and organization relations of compatibility and congruence are established, increasing the tendency towards psychological success.

The individual is convinced that their interests coincide with those of the organization.

Therefore, a useful solution to this process is lifelong learning, regular sessions of training and personal, psychological development for leaders, self-improvement, accessing intrinsic needs of self-actualization and overtaking, practical exercise and perseverance in developing psychosocial skills.

\section{BIBLIOGRAPHY}

[1] Adair, J., Leadership strategic, Ed. Meteor Publishing, București, 2015.

[2] Adair, J., Cum să formezi lideri, Ed. Meteor Publishing, București, 2015.

[3] Boncu,Șt., Dafinoiu,I., Psihologie socială clinică, Ed. Polirom, Iași, 2014.

[4] Cristea,D., Tratat de psihologie socială, Ed.TREI, București, 2015.

[5] Ewen, R., Introducere în teoriile personalității, Ed. TREI, București, 2012.

[6] Lazarus, R., Emoție și adaptare, Ed. TREI, București, 2011.

[7] Maxwell, J., Totul despre Lideri, Atitudine, Echipă, Relații, Ed. Amaltea, București, 2005.

[8] Zlate,M., Leadership și management, Ed. Polirom, Iași, 2004.

[9] Zlate,M., Fundamentele psihologiei, Ed. Universitară, București, 2006.

[10] Zlate,M., Tratat de psihologie organizațional-managerială, vol.II, Ed. Polirom, lași, 2007. 